\title{
Edaphic and arboricolous oribatid mites (Acari; Oribatida) in tropical environments: changes in the distribution of higher level taxonomic groups in the communities of species
}

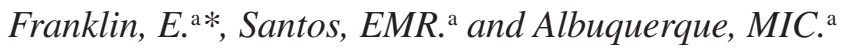 \\ anstituto Nacional de Pesquisas da Amazônia - INPA, CPEn, Avenida André Araújo, 2936, Petrópolis, \\ CEP 69060-001, Manaus, AM, Brazil \\ *e-mail: beth@inpa.gov.br
}

Received August 19, 2005 - Accepted October 25, 2005 - Distributed August 31, 2007

(With 2 figures)

\begin{abstract}
We analysed the community of oribatid mites in 25 environments of northern Brazil and one in a rain forest in Peru, encompassing fauna sampled on natural and artificial (nylon-mesh bags) substrata, from primary and secondary forests, caatinga, savannahs, flooded forests, bark and epiphytes of trees, and polyculture. A hundred and forty six species are definitively identified from a total of 444 taxa. To determine changes in the community, we took as a basis of comparison the species dominance of Lower Oribatida vs. Oppioidea and Lower Oribatida vs. Poronota. Even considering the different periods in which the inventories were realized and the different sampling methodology compared, the partition of the species of Oribatid mite in larger groups shows tendencies indicating partition of species dominance among the environments studied, showing that they differed in their suitability as habitats for the Oribatid mite community, mainly in respect to the Lower Oribatida, Oppioidea and Poronota composition. These tendencies should be explored in more detail as more becomes known about the species composition in each environment.
\end{abstract}

Keywords: humid tropics, Lower Oribatida, Oppioidea, Poronota, soil invertebrates.

\section{Oribatídeos (Acari; Oribatida) edáficos e arborícolas em ambientes tropicais: mudanças na distribuição de grupos taxonômicos superiores nas comunidades de espécies}

\begin{abstract}
Resumo
Analisou-se comunidade de ácaros oribatídeos em 25 ambientes do Norte do Brasil e em uma floresta no Peru, compreendendo fauna de substratos naturais e artificiais (sacos de malha) coletada em florestas primárias, florestas secundárias, caatinga, savanas, florestas inundáveis, casca e epífitas de árvores e policultivo. Cento e quarenta e seis espécies são definitivamente identificadas de um total de 444 taxa. Foram comparadas as dominâncias de espécies de Oribatida Inferior vs. Oppioidea e Oribatida Inferior vs. Poronota para determinar as mudanças na comunidade. Mesmo considerando os diferentes períodos dos inventários e as diferentes metodologias de coleta comparadas, a partição de espécies de Oribatida em grandes grupos mostra tendências que podem ser indicadoras da partição da dominância entre os ambientes estudados, indicando que eles diferiram em suas qualidades como habitat para a comunidade de ácaros oribatídeos, principalmente no que diz respeito à composição dos Oribatida Inferiores, Oppioidea e Poronota. Essas tendências devem ser exploradas com mais detalhes à medida que se conheça mais sobre a composição das espécies em cada ambiente.
\end{abstract}

Palavras-chave: Acari Oribatida, Oribatida Inferiores, Oppioidea, Poronota, trópicos úmidos.

\section{Introduction}

One of the numerous impediments to the study of biodiversity is that some groups include so many species that most of them are still undescribed, requiring highly qualified and skilled experts, and specimens are often identified at high taxonomic levels or as morphospecies (Noti et al., 2003). The proportion of morphospecies that cannot be assigned to named species and the number of scientist-hours required to process samples both increase dramatically for smaller-bodied taxa (Lawton et al., 1998). This obviously applies to mites, mainly in the Amazon region. For decades, many authors have been emphasizing the lack of data likely to support any assumption regarding the diversity of soil mites in the tropics (Usher, 1988; André et al., 1992; Noti et al., 2003). In 
small spatial scale inventories ( 0.16 to $1.0 \mathrm{ha}$ ) in primary forest sites of Central Amazon, with an average duration of 6 months, the dominance of oribatid mites in relation to the total number of the mesofauna was over $50 \%$, and the known diversity was high, varying from 71-95 sampled species (Franklin, 1994; Franklin et al., 1997a, b; Franklin, 1998; Franklin et al., 2001). In Panguana, Peru, almost 200 species were registered in a low land forest (Wunderle, 1985, 1992).

The use of higher-taxon levels as surrogates for species avoids the labor intensive, time-consuming and costly nature of species-level identification (Pik et al., 1999). On the level of higher taxa as well on the species level of the oribatid mites, the statistical range of abundance and the relative frequency of those taxa form a basis for determining changes within a given conenoses and to interpret them (bioindication). Therefore, the ordinations of species must follow a systematic organization in order to be grouped and used for meaningful biological interpretation of collected data (Beck et al., 1997). Woas (2002) organized the species and morphospecies of oribatid mites collected in the Brazilian State of Amazonas, according to the morphological (and ontogenetic) organization and to the systematic groups of Oribatida, including information about the species' ecology and distribution. Another functional and/or ecological classification already used for Collembola (Gisin, 1943) can also be applied to the Acari (Wallwork, 1967; Cancela da Fonseca, 1987; Lavelle, 2001). It consists of a vertical habitat grouping of animals living uppermost (epi-) to the ones living in the soil (eu-) and the intermediate hemiedaphics. Epiedaphic Acari tolerate desiccation better than hemi- and euedaphic forms (Lavelle, 2001). Among the oribatid mites, the Oppioidea and Lower Oribatida are known as euedaphic fauna (Woas, 2002). Beck et al. (1997) compared 108 worldwide environments representing temperate or cooler wood- and open land, and found tendencies in the relative amount of species of the larger groups of oribatid mites within the total number of species in a locality (species-dominance): for example, in cold and wet environments the species-dominance of Lower Oribatida increases, as the species-dominance of Poronota reduces. By comparison, in warm and dry environments the species-dominance of Poronota increases, as the species-dominance of Lower Oribatida reduces.

Therefore, considering the results of published studies, and assuming that the affiliation of various species to the larger groups is sufficient for the state of knowledge at this time, we are analyzing the list provided by Franklin et al. (2006). We are also giving a general overview about the partition of the groups of Oribatida, through the comparison of species-dominance of Lower Oribatida vs. Oppioidea and Lower Oribatida vs. Poronota in 25 environments of northern Brazil and one in a rainforest in Peru.

\section{Methods}

The list of species and morphospecies recorded in the Brazilian states of Amazonas, Roraima, Rondônia and
Pará, and in Panguana (Peru) is based on bibliographic references (Table 1) and from Franklin et al. (2006). The list elaborated by Franklin et al. (2006) excluded species deriving from studies where the basic information could not be clearly localized, like the correct name of the place of sampling, type of vegetation, and the morphospecies identified at the level of family. Nomenclature and systematic organization of the list followed the morphological (and ontogenetic) organization and systematic groups of Oribatida proposed by Woas (2002), who recommended that the establishment of well-defined higher taxa is a task still requiring intense work of revision. Therefore, instead of definitive higher taxa, he adopted only groups, largely conforming to Grandjean (1953), assigned to different levels of organization. Author names for genera, families and higher taxa were listed according to Balogh (1972), Balogh and Balogh (1992) and Grandjean (1953, 1965, 1969). The names of the species were cited as the original publications, with small corrections in the orthography. Therefore, Subias (2004) and other monographs must be consulted to follow the possible changes occurred with the name of the species and genera. The morphospecies were included because of two common procedures among oribatidologists: 1) the identifications are restricted to "adult" mites (Noti et al., 2003), and 2) the inclusion of morphospecies in most field analysis. Also, according to Beck et al. (1997), investigations based on higher groups of oribatid do not require exact knowledge of the taxonomical status of their species. The morphospecies names were listed following the sequence of the original publication, and we must be aware that, for example, Pergalumna sp. A of one specific environment cannot be the same species of another. The places and methodology of sampling is given in Table 1. However, original publication should be consulted for more specific information.

In the results and discussion, we present a general overview of the faunistic partition of the studied environments, having as a basis the available data of the literature, independently of the time, sampling method and experimental design of each study. The subdivision of the Lower Oribatida in three levels (A, B and C) and of the Higher Oribatida in four levels (Levels A, B, C and D) was ordered according to Woas (2002). Therefore, to determine changes in the communities, we took as a basis of comparison the species dominance of Lower Oribatida vs. Oppioidea and Lower Oribatida vs. Poronota.

\section{Results}

To date, 146 species have been definitively identified from a total of 444 taxa, totalizing 188 known genera (see Franklin et al., 2006). The relative amount of species of the larger groups within the total number of species (species dominance) was compared among the 26 environments (Table 2).

Comparing the species dominance of Lower Oribatida vs. Oppioidea on natural substrata, the upper limit of the 


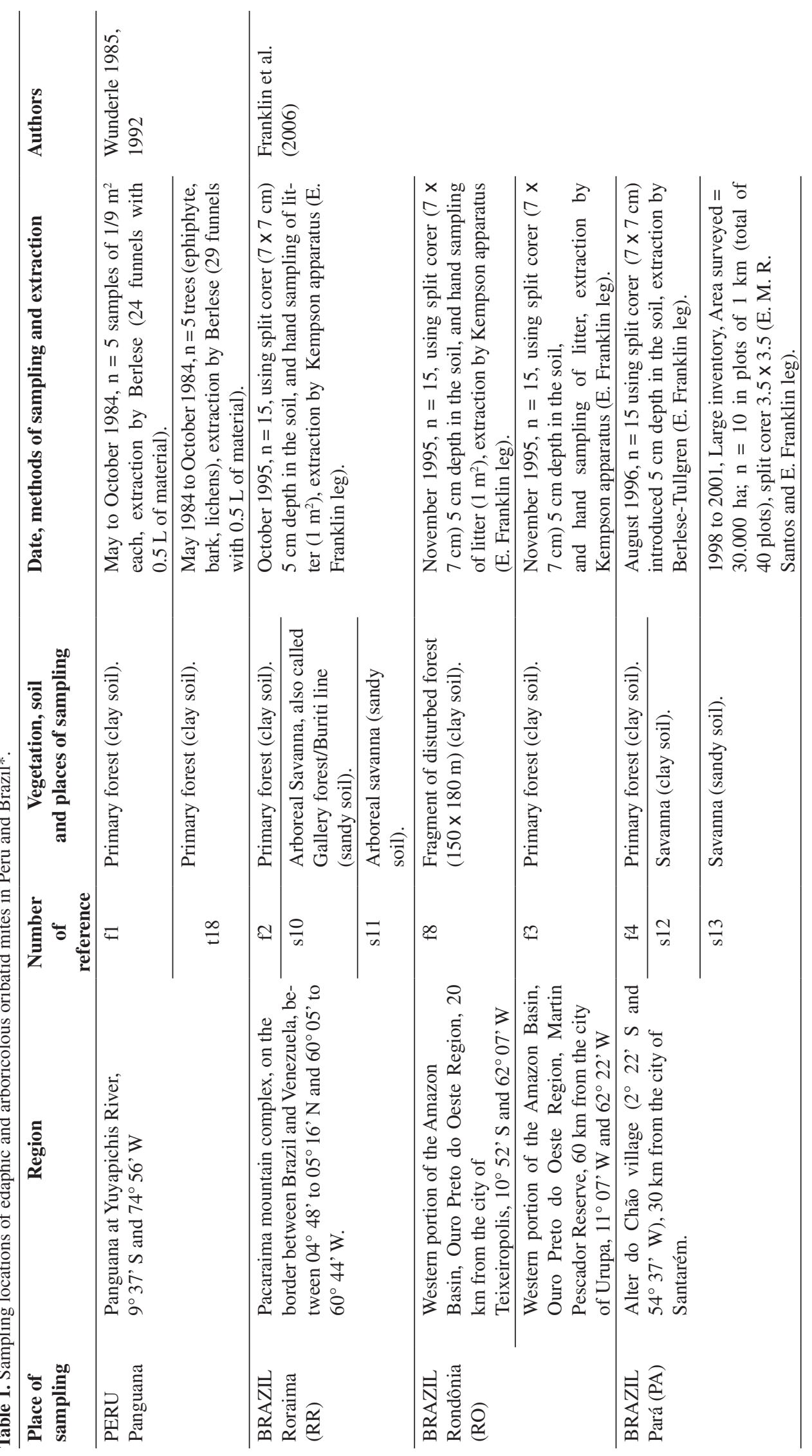




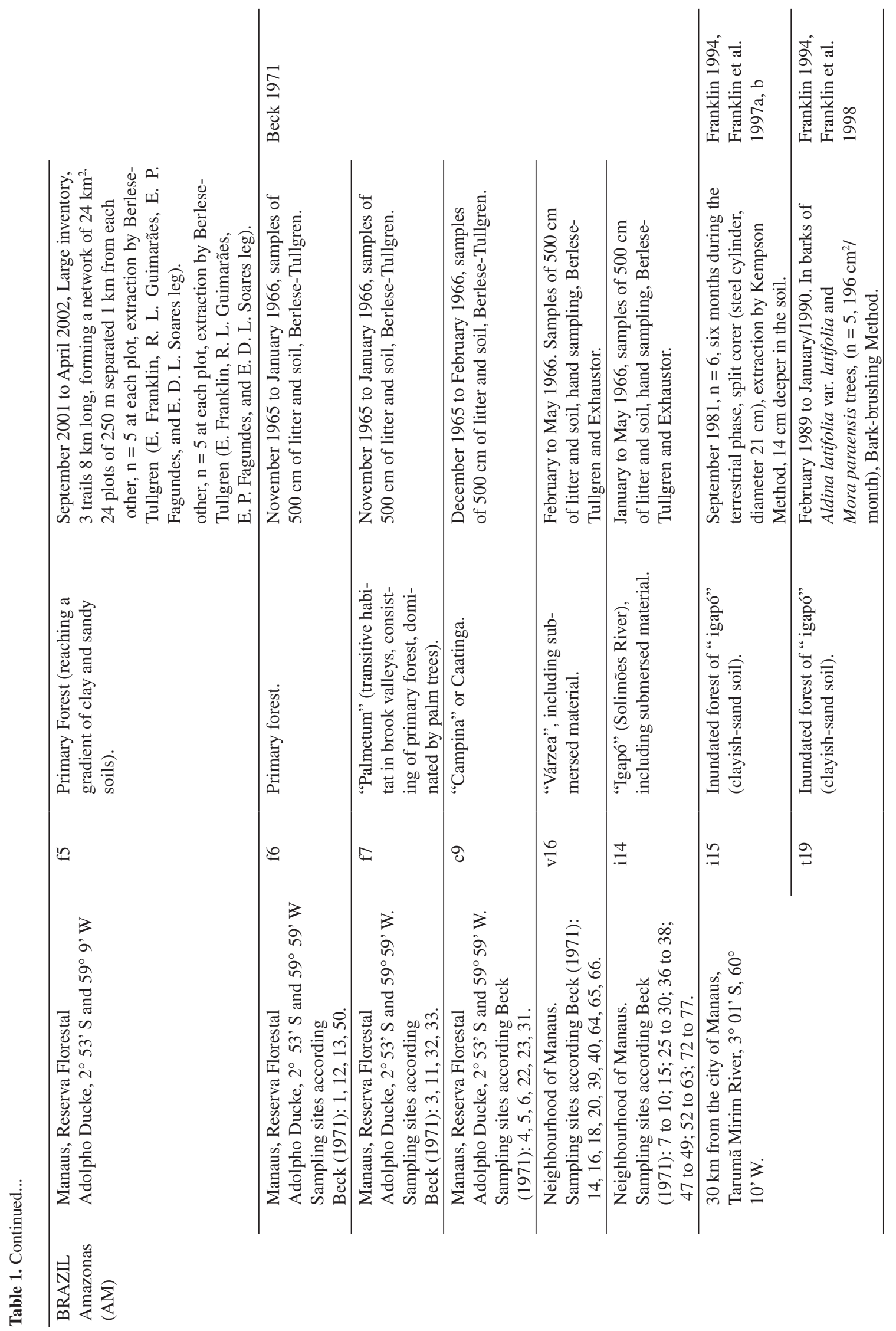




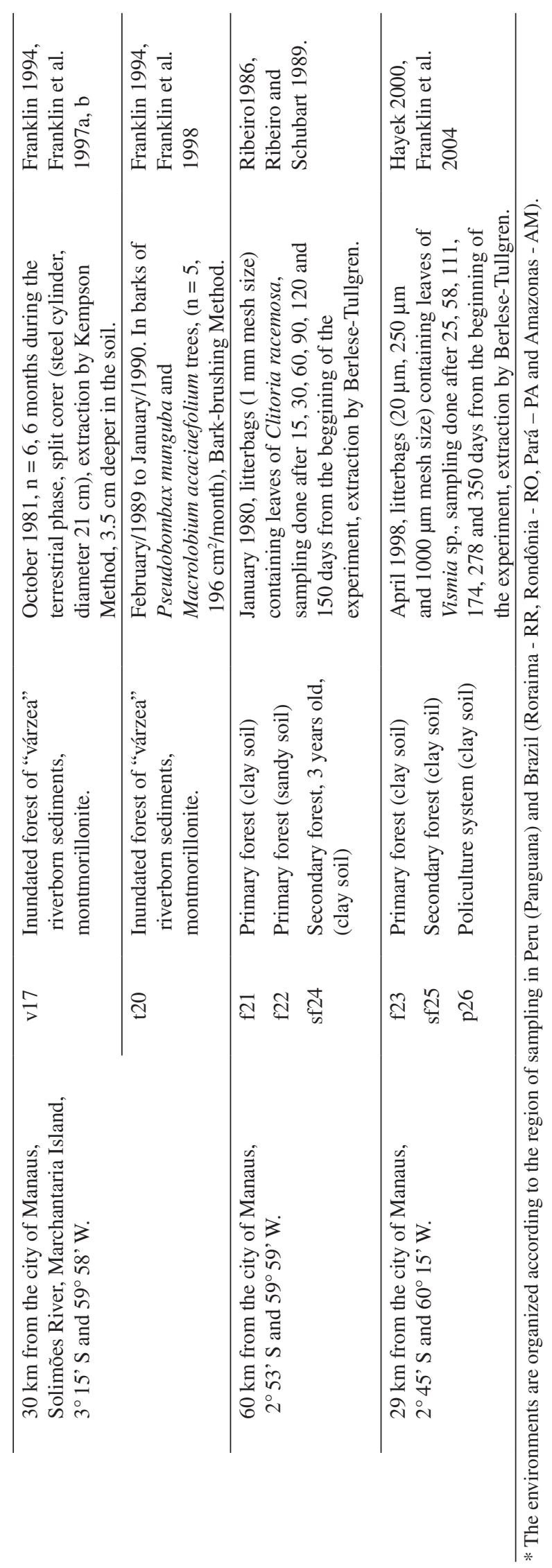




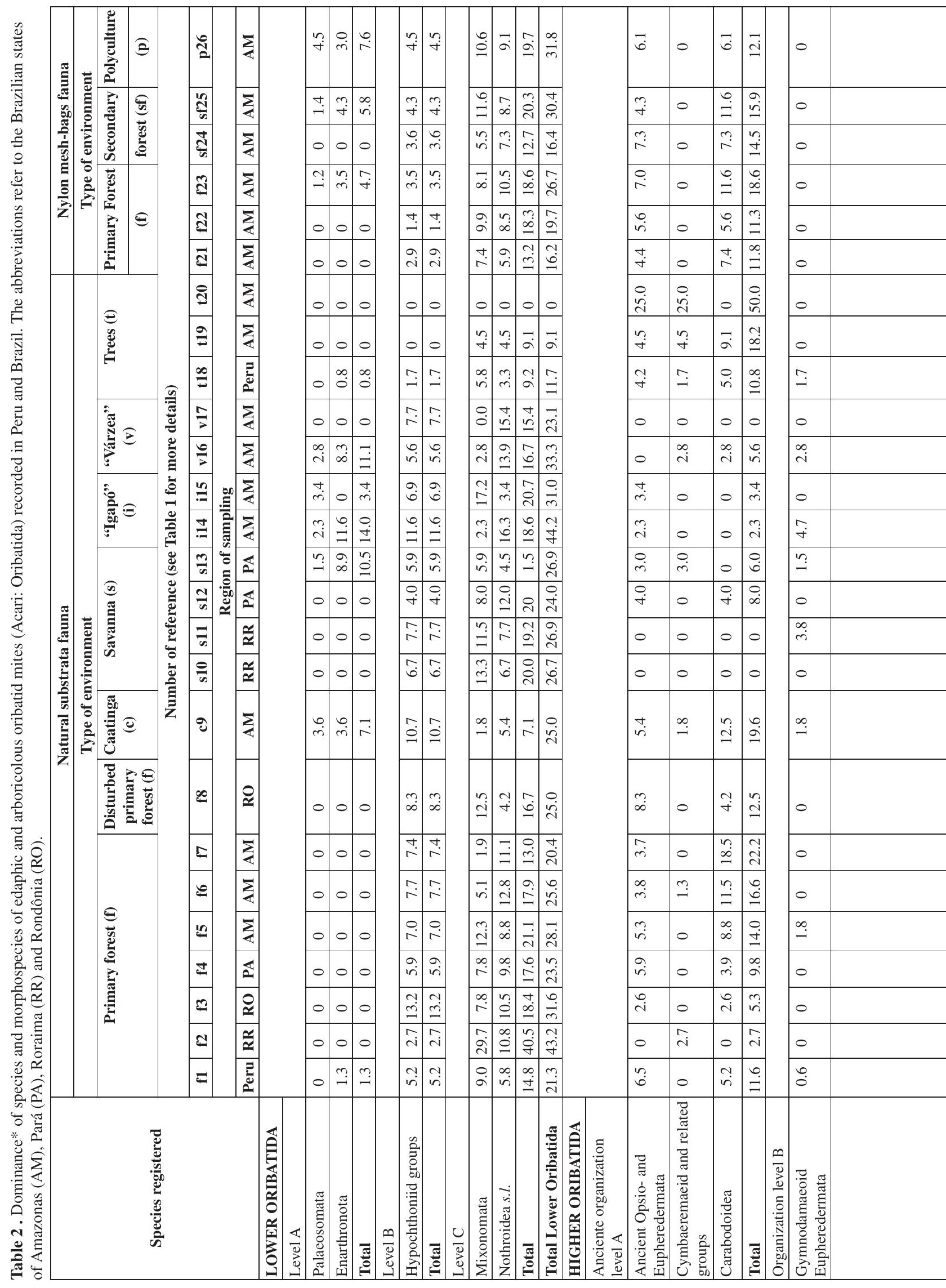


punctuated line in Figure 1a shows the environments where the sum of both groups was higher than $35 \%$ compared to the other oribatid mites groups (Table 2), and that would represent a habitat suitable for euedaphic fauna. The dominance of Lower Oribatida is exceptionally high (44.2\%) in the "igapó" (i14) of Amazonas and in the primary forest (f2) in Roraima (43.2\%). The ratio Lower Oribatida/Oppioidea shows that in these regions we obtained respectively 4.8 and 5.3 more species of Lower Oribatida than Oppioidea (Table 3). In the "igapó" (i15) the dominance of Lower Oribatida can also be considered very high $(31 \%)$ compared to Oppioidea (ratio $=3.0$ ). In the primary forest of Rondônia (f3) and in the savannas (s12 and s13) of Pará the dominance of Lower Oribatida over Oppioidea is reduced to the ratio of 2.0, 1.5 and 1.3, respectively. The low dominance of Oppioidea in the savannahs of Roraima (s10, s11) differentiates these environments from the savannah of Pará (s12, s13) (Figure 1a). In the two savannahs in Roraima, the ratio is 7.0 and 26.7, which means an average probability of finding 16.8 more species belonging to Lower Oribatida compared to Oppioidea. In Pará the ratio is reduced to 1.3 and 1.5 (average $=1.4$ ), respectively.

Comparing the species dominance of Lower Oribatida vs. Oppioidea on artificial substrata (nylonmesh bags), two distinct groups are formed (Figure 1b). The primary forest (f23), the secondary forest (sf25) and the polyculture (p26), whose samples came from nylon-mesh bags containing leaves of Clitoria racemosa (Cecropia), composed one group. The ratio Lower Oribatida/Oppioidea varies between 2.9-4.2, which represents an average probability of finding 3.4 more species belonging to Lower Oribatida (Table 2 and 3). The two primary forests (f21 and f22) and the secondary forest (sf24), whose samples came from nylon-mesh bags containing leaves of Vismia sp. ("Lacre"), composed the second group, through the reduction of the ratio to 0.8 1.4 (average $=1.2$ ).

Comparing the species dominance of Lower Oribatida vs. Poronota on natural substrata, the upper limit of the line in Figure 2a shows the environments where the sum of both groups is higher than $50 \%$. Following the criteria established by Beck et al. (1997), above this diagonal line, a more extreme habitat for the oribatid mites is represented (Table 2). Comparing the fauna sampled on natural substrata, in the várzea of Amazonas (v17) and in the primary forest in Roraima (f2), the dominance of both groups is the highest compared to the other 24 environments $(67.5 \%)$. The ratio Lower Oribatida/Poronota was 0.5 and 1.8 , respectively. In the savannahs (s10 and s11) of Pará and of Roraima (s12), in the disturbed primary forest (f8) of Rondônia, and in the primary forests of Amazonas (f5), the dominance of both groups among the other oribatid mites groups is also high, varying between 50 and 59.6\%. In the "igapó" (i14) and in the primary forest (f2), the ratio Lower Oribatida/Oppioidea shows that in these regions we obtained respectively 6.3 and 1.8 more species of Lower Oribatida than Oppioidea (Table 3). The environments from the region of Roraima are differentiated by the percentage of both groups. Compared to the other 25 environments, the primary forest (f2) exhibits one of the highest dominance of Lower Oribatida + Poronota $(67.5 \%)$. This variation differentiates this forest from the two savannahs in Roraima, whose percentage for both groups was lower than $55 \%$ (53.4 and $53.8 \%$, respectively) (Table 2). The percentag-

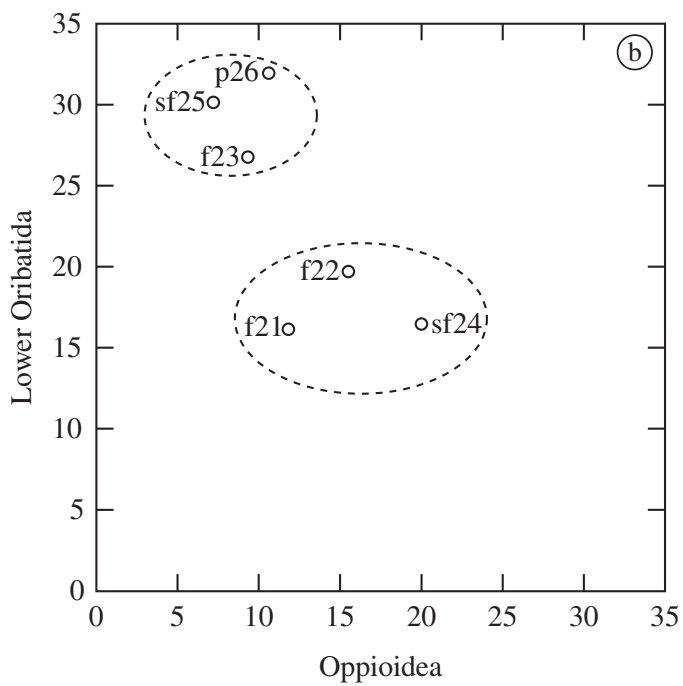

Figure 1. Species dominance (\%) of Oppioidea and Lower Oribatida in 26 environments. a) Natural substrata; and b) Artificial substrata (nylon-mesh bags). The punctuated transversal line delimitates those habitats where the sum of Oppioidea and Lower Oribatida is higher than $35 \%$. Symbols for vegetation are: $\mathrm{f}=$ primary forest, $\mathrm{sf}=$ secondary forest, $\mathrm{c}=$ caatinga, $\mathrm{p}=$ polyculture, $\mathrm{s}=$ savannah, $\mathrm{v}=$ várzea, $\mathrm{i}=$ "igapó" and $\mathrm{t}=$ trees. Symbols for regions are: asterisks $=$ Pará $(\mathrm{PA})$, circles $=$ Amazonas $(\mathrm{AM})$, exes $=$ Rondônia $(\mathrm{RO})$, squares $=$ Roraima $(\mathrm{RR})$ and triangles $=$ Peru. 

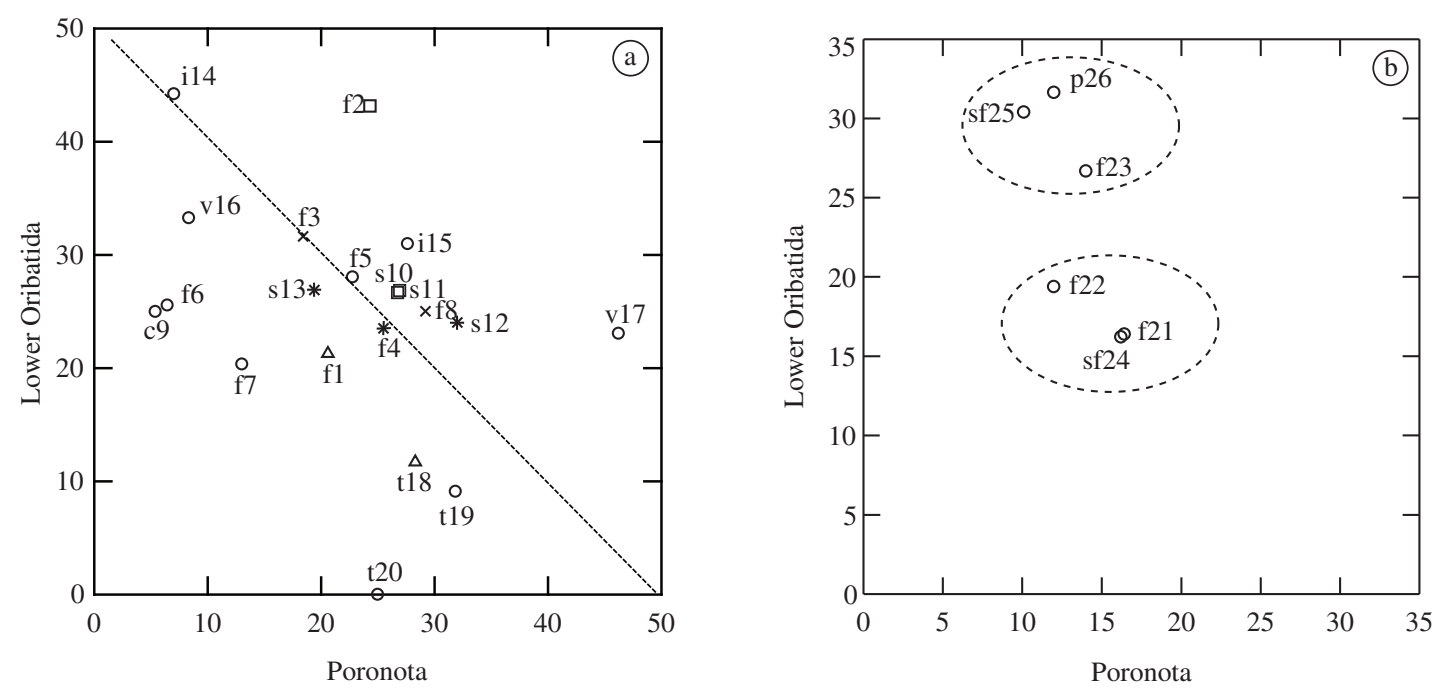

Figure 2. Species dominance (\%) of Poronota and Lower Oribatida in 26 environments. a) Natural substrata; and b) Artificial substrata (nylon-mesh bags). The punctuated transversal line delimitates those habitats where the sum of Poronota and Lower Oribatida is higher than $50 \%$. Symbols for vegetation are: $\mathrm{f}=$ primary forest, $\mathrm{sf}=$ secondary forest, $\mathrm{c}=$ caatinga, $\mathrm{p}=$ polyculture, $\mathrm{s}=$ savannah, $\mathrm{v}=$ várzea, $\mathrm{i}=$ "igapó" and $\mathrm{t}=$ trees. Symbols for regions are: asterisks $=$ Pará $(\mathrm{PA})$, circles $=$ Amazonas $(\mathrm{AM})$, exes = Rondônia $(\mathrm{RO})$, squares = Roraima $(\mathrm{RR})$ and triangles $=$ Peru.

Table 3. Amount of Lower Oribatida with respect to Oppioidea and Lower Oribatida with respect to Poronota. The list follows the same sequence of Table 2 .

\begin{tabular}{|c|c|c|c|c|c|}
\hline $\begin{array}{c}\text { Type of } \\
\text { substrata }\end{array}$ & Vegetation/Symbol & $\begin{array}{c}\text { Reference } \\
\text { number }\end{array}$ & Region & $\begin{array}{c}\text { Lower } \\
\text { Oribatida / } \\
\text { Oppioidea }\end{array}$ & $\begin{array}{c}\text { Lower } \\
\text { Oribatida / } \\
\text { Poronota }\end{array}$ \\
\hline \multirow[t]{20}{*}{ Natural } & \multirow[t]{7}{*}{ Primary Forest (f) } & f1 & PERU & 1.8 & 1.0 \\
\hline & & $\mathrm{f} 2$ & $\mathrm{RR}$ & 5.3 & 1.8 \\
\hline & & $\mathrm{f} 3$ & $\mathrm{RO}$ & 2.0 & 1.7 \\
\hline & & $\mathrm{f} 4$ & $\mathrm{PA}$ & 1.3 & 0.9 \\
\hline & & f5 & $\mathrm{AM}$ & 8.0 & 1.2 \\
\hline & & f6 & AM & 25.6 & 4.0 \\
\hline & & f7 & AM & 20.4 & 1.6 \\
\hline & Primary forest, disturbed (f) & f8 & RO & 25.0 & 0.9 \\
\hline & Caatinga (c) & c9 & AM & 6.9 & 4.6 \\
\hline & \multirow[t]{4}{*}{ Savannah (s) } & s10 & $\mathrm{RR}$ & 26.7 & 1.0 \\
\hline & & s11 & $\mathrm{RR}$ & 7.0 & 1.0 \\
\hline & & s12 & PA & 1.5 & 0.8 \\
\hline & & s13 & PA & 1.3 & 1.4 \\
\hline & \multirow[t]{2}{*}{ "Igapó” (i) } & i14 & $\mathrm{AM}$ & 4.8 & 6.3 \\
\hline & & i15 & $\mathrm{AM}$ & 3.0 & 1.1 \\
\hline & \multirow[t]{2}{*}{ “Várzea" (v) } & v16 & $\mathrm{AM}$ & 11.9 & 4.0 \\
\hline & & v17 & $\mathrm{AM}$ & 23.1 & 0.5 \\
\hline & \multirow[t]{3}{*}{ Trees $(\mathrm{t})$} & $\mathrm{t} 18$ & PERU & 0.9 & 0.4 \\
\hline & & $\mathrm{t} 19$ & $\mathrm{AM}$ & 2.0 & 0.3 \\
\hline & & $\mathrm{t} 20$ & AM & 0.0 & 0.0 \\
\hline \multirow[t]{6}{*}{ Artificial } & \multirow[t]{3}{*}{ Primary Forest (f) } & $\mathrm{f} 21$ & AM & 1.4 & 1.0 \\
\hline & & f22 & AM & 1.3 & 1.6 \\
\hline & & $\mathrm{f} 23$ & $\mathrm{AM}$ & 2.9 & 1.9 \\
\hline & \multirow[t]{2}{*}{ Secondary Forest (sf) } & sf24 & $\mathrm{AM}$ & 0.8 & 1.0 \\
\hline & & sf25 & AM & 4.2 & 3.0 \\
\hline & Polyculture (p) & p26 & $\mathrm{AM}$ & 3.0 & 2.6 \\
\hline
\end{tabular}


es obtained from trees (t18, t19 and t20) were analogous, showing dominance of Poronota.

As we also noticed when comparing Lower Oribatida vs. Oppioidea, the species dominance of Lower Oribatida and Poronota on artificial substrata (nylon-mesh bags) shows two distinct groups (Figure 2). The primary forest (f23), the secondary forest (sf25) and the polyculture (p26), whose samples came from nylon-mesh bags containing leaves of Clitoria racemosa (Cecropia), compose one group. The ratio Lower Oribatida/Poronota varies among $1.9-3.0$, which represents an average probability to find 2.5 more species belonging to Lower Oribatida (Table 2 and 3). The two primary forests (f21 and f22) and the secondary forest (sf24), whose samples came from nylon-mesh bags containing leaves of Vismia sp. (Lacre), composed the second group, through the reduction of the ratio to 1.0 to 1.6 (average $=1.6$ ) (Figure $2 b$, Table 2 and 3 ).

\section{Discussion}

On natural substrata, the main difference detected through the comparison of Lower Oribatida vs. Oppioidea, is the exceptionally high dominance of Lower Oribatida in an inundated forest of "igapó" (i14) in Amazonas and in a primary forest (f2) in Roraima. It is also noticeable that both savannahs in Roraima (s10 and s11) are different in respect to the dominance of Lower Oribatida and Oppioidea, probably because the savannah s10 (Roraima) is situated along a gallery forest (Buriti line), that is partially covered by water in some periods of the year. The "igapó" represent disturbed environments, covered by the floodwater of the Amazonian rivers during 4-6 months a year. These results show that the water content in the soil can be one of the key factors regulating the ratio Lower Oribatida/Oppioidea on natural substrata. The dominance of Oppioidea is higher in the savannahs in Pará, compared to the savannahs in Roraima. The region of Roraima represents a drier environment of the Pacaraima mountain complex, on the border between Brazil and Venezuela.

The litter layer in tropical rainforests is relatively weakly developed when compared to the more temperate or cooler woodland on the globe, and the diversity and density of Oppioidea is much lower compared to temperate or cooler forests (Beck et al., 1997; Woas, 2002). For example, the ratio between Lower Oribatida vs. Oppioidea was compared in twelve sampled sites in three temperate forests in Germany (Schwartzwald, Odenwald and Oberrheinebene). In ten of these sites, the ratio varied between $0.13-0.98$ (average $=0.43$ ). In only two forests the ratio was 1.23 and 1.69 (average $=1.46$ ). For the environments here studied, the ratio result on natural substrata varies from zero to 26.7 (average $=8.9$ ). On artificial substrata, the ratio varied from 0.8 to 4.2 (average $=2.3$ ), effectively showing that Oppioidea did not exceed the limit of $20-25 \%$ dominance in the tropical regions here studied. For another comparative example, in two temperate forests from Germany (Bruchsaler Wald and Stadtwald Ettlingen), the dominance of Oppioidea was 58.5 and $62.1 \%$, respectively (Beck et al., 1997).

The Oppioidea are dominant in environments with great concentrations of decaying plant material and a non-compacted soil structure (Woas, 2002; Franklin et al., 1997b; Franklin et al., 2004) and they can invade more open terrain, tending to live in a thick layer of decaying plant material in savannah, steppe, salt marsh and related biomes (Beck et al., 1997). In tropical rainforests they may reach a higher number of species and a higher population density if the input of decaying plant material on the soil is increased (Woas, 2002). In the secondary forest (sf24) the relatively dense litter fall of plants (Cecropia) increases the thickness of the litter layer (Franklin et al., 1997a; Woas, 2002; Martius et al., 2004), which can explain the reduction of the dominance of Lower Oribatida over Oppioidea to a ratio of only 1.2 on average. Therefore, we did not register the same tendency for the other secondary forest ( $\mathrm{sf25}$ ), probably because the rather thinner litter layer was mostly composed of leaves of Vismia sp. ("Lacre"), that are smaller and less palatable compared to the leaves of Clitoria racemosa (Franklin et al., 2004). Therefore, the dominance of Lower Oribatida over Oppioidea increased to the ratio of 3.4 on average. Hence, in the case of artificial litter, we confirm the tendency of Oppioidea as edaphic fauna.

The composition of Lower Oribatida vs. Oppioidea and Lower Oribatida vs. Poronota separated two groups according to the leaves enclosed in the nylon-mesh bags. The samples that came from litterbags containing leaves of $C$. racemosa, placed on the soil surface of three forests (a primary and a secondary forest on yellow latosol, and a primary forest on hydromorphic soil), composed one group. The samples that came from litterbags containing leaves of Vismia sp., placed on the soil surface of a primary forest, a secondary forest and a polyculture (yellow latosol), composed the second group. As in both groups the samples came from different types of forest and soil, we conclude that the common factor was the species of leaves enclosed in the nylon-mesh bags. According to Coleman and Crossley (1996), the oribatid mite populations are influenced by biotic factors such as residue input into soil. In a mesic mixed hardwood forest in the Nantahala Mountains of North Carolina, USA, a link between heterogeneity and diversity of mites active in a particular horizon of litter and some influence of littertype upon species composition was registered (Hansen and Coleman, 1998). In the south east of Brazil, the oribatid mite densities and activity at the soil surface were monitored under three species of perennial legume cover crops in a derived savannah zone. Factors other than rainfall and temperature influenced the densities of soil oribatid mites. These factors were determined by the differences between the treatment in terms of vegetation cover, presence of residues, food availability and palatability and their consequent effects on soil conditions (AdetolaBadejo et al., 2002). Our results suggest that the litter- 
type exerted greatest influence upon species composition, reflecting also in the group composition in higher levels of oribatid mites. Others factors, not tested here, would be the humidity and the fungi community colonizing the leaves. According to Franklin et al. (2004), the bags represent a very artificial and humid environment and their oribatid mite community is different from the normal fauna found in natural conditions in the tropics.

In more temperate or cooler woodland the maximum percentage for Lower Oribatida + Poronota, is around $60 \%$ (Beck et al., 1997). In the primary forest (f2) in Roraima and the várzea (v17) in Amazonas, the percentage of both groups was $67.5 \%$ and $69.3 \%$. This tendency for the várzea has already been detected by Franklin et al. 1997a, b. The fragment of forest (f8) in Rondonia was also situated on the extreme limit.

It is noticeable that in our study, none of the nondisturbed primary forest was situated out of the extreme limit. The primary forest (f2) in Roraima and the várzea (v17) are warmer and drier environments, compared to the others. The disparity between the percentages obtained in the two environments of várzea is probably because one (s17) is situated on an island (Ilha de Marchantaria, Amazonas), and the other (s16) is characterized by Beck (1971) as a mixed water region. The ratio between Lower Oribatida with respect to Poronota, differentiate the environments in Roraima, as the primary forest (f2), with higher soil humidity and showing higher percentage of Lower Oribatida, is different from the savannahs (s10 and s11). Associated with the water content in the soil, the balance between humid vs. drier environments appears as another factor regulating the ratio Lower Oribatida/Poronota, agreeing with the results of Beck et al. (1997).

Observance of differential species, the relative frequency of species and the nature of ecological information can propitiate distinction and characterization of the coenoses as animal communities and to classify them, i.e. as synusia (Beck et al., 1997). Central to the use of community level characteristics as bioindicators is knowledge of the taxonomy and ecology of species in the community. Integration of ecological and biological data on species assemblages with geographical information system (GIS) data on soil physical parameters, other biotic components, climate and vegetation, could potentially provide assessments of habitat complexity and change under stress for large spatial scales, and allow comparison between habitats (Behan-Pelletier, 1999). Therefore, the tendencies detected in our study, can be explored in more detail when more becomes known about the species composition. In our study, even considering the different periods in which the inventories were carried out and sampling methodology compared, the partition of the species of Oribatid mites in larger groups showed tendencies indicating the partition of species dominance among the environments, indicating that they differed in their suitability as habitat for the Oribatid mites community, mainly in respect to the Lower Oribatida, Oppioidea and Poronota composition.
Otherwise, the high number of 298 non-described species (morphospecies) clearly shows the inadequacy of present taxonomic knowledge for the region and the need for studies to determine the species composition of the communities of oribatid mites in South America. Similar to what is happening with Collembola, another mega diverse group, a large number of undescribed species in Brazil are being accumulated in collections, most of them remaining unknown to science (Culik et al., 2003). Therefore, considering the hyperdiverse groups, it is necessary to find solutions for the extreme time necessary to make the formal species identifications. Because of the use of bioinformatic technology, the acceptance of the use of morphospecies identification is currently one of the questions being discussed by many authors (Oliver and Beattie, 1993; Oliver, 1997; Oliver et al., 2000).

Acknowledgments - Financial support came from the "Edital Universal CNPq 47-2978/03-9, Reserva Florestal Adolpho Ducke (RFAD): Um modelo amazônico para o inventário e caracterização da biodiversidade", "PNOPG-550409/01-7, Populações e comunidades de invertebrados do solo da Reserva Adolpho Ducke, Manaus, AM" and "PPD-G7 6400-0021: As interações entre savanas e florestas na Amazonia Central e sua importância para a biodiversidade". We are thankful to DAAD (the German Academic Exchange Service) for a scholarship, and to Dr. S. Woas, and to Dr. L. Beck (Staatliches Museum für Naturkunde Karlsruhe, Germany) for their essential teaching.

\section{References}

ADETOLA BADEJO, M., ESPINDOLA, JAA., GUERRA, JGM., AQUINO, AM. and CORREA, MEF., 2002. Soil oribatid mite communities under three species of legumes in an ultisol in Brazil. Experimental and Applied Acarology, vol. 27, no. 4, p. 283-296.

ANDRÉ, HM., LEBRUN, PH. and NOTI, MI., 1992. Biodiversity in Africa: a plea for more data. Journal of African Zoology, vol. 106, p. 3-15.

BALOGH, P., 1972. The oribatid genera of the world. Acad. Kiado, Budapest. 188p.

BALOGH, J. and BALOGH, P., 1992. The oribatid mite genera of the world. Vols. 1, 2. Budapest: Hungarian National Museum Press.

BECK, L., 1971. Bodenzoologische Gliederung und Charakterisierung des amazonischen Regenwaldes. Amazoniana, vol. 3, no. 1, p. 69-132.

BECK, L., WOAS, S. and HORAK, F., 1997. Taxonomische Ebenen als Basis der Bioindikation - Fallbeispiele aus der Gruppe der Oribatiden (Acari). Abh. Ber. Naturkundemus, Görlitz, vol. 69, no. 2, p. 67-85.

BEHAN-PELLETIER, VM. 1999. Oribatid mite biodiversity in agroecosystems: role for bioindication. Agriculture, Ecosystem and Environment, vol. 74, no. 1-3, p. 411-423.

CANCELA DA FONSECA, JP., 1987. About the ecological niches of three Beech litter panphytophage oribatid mites. In: STRIGANOVA, BR. (Ed). Soil Fauna and Soil Fertility. $9^{\text {th }}$., International Colloquium on Soil Zoology. Moscow "Nauka", Moscow, p. 289-295. 
COLEMAN, D. and CROSSLEY, DA., 1996. Fundamentals of Soil Ecology. Academic Press, San Diego, 205p.

CULIK, MP. and ZEPPELINI-FILHO, D., 2003. Diversity and distribution of Collembola (Arthropoda: Hexapoda) of Brazil. Biodiversity and Conservation, vol. 12, p. 1119-1143.

FRANKLIN, E., 1994. Ecologia de oribatídeos (ACARI: ORIBATIDA) em florestas inundáveis da Amazônia Central. Ph. D. Thesis, INPA/Amazon University, Manaus, 266p.

FRANKLIN, E., MORAIS, JW. and SANTOS, EMR., 2001. Density and biomass of Acari and Collembola in primary forest, secondary regrowth and polycultures in central Amazonia. Andrias, vol. 15, no. 1, p. 141-154.

FRANKLIN, E., HAYEK, T., FAGUNDES, EP. and SILVA, LL., 2004. Oribatid mites (Acari: Oribatida) contribution to decomposition dynamic of leaf litter in primary forest, second growth and polyculture in the Central Amazon. Revista Brasileira de Biologia, vol. 64, no. 1, p. 59-72.

FRANKLIN, EN., ADIS, J. and WOAS, S., 1997a. The Oribatid Mites. In JUNK, WJ. (ed.), Central Amazonian river floodplains: ecology of a pulsing system. Springer-Verlag, Berlin, Heidelberg, p. 331-349.

FRANKLIN, EN., SCHUBART, HOR. and ADIS, JU., 1997b. Ácaros (ACARI: ORIBATIDA) edáficos de duas florestas inundáveis da Amazônia Central: Distribuição vertical, abundância e recolonização do solo após a inundação. Revista Brasileira de Biologia, vol. 57, no. 3, p. 501-520.

FRANKLIN, EN., WOAS, S., SCHUBART, H.O.R. and ADIS, J., 1998. Ácaros oribatídeos (Acari: Oribatida) arborícolas de duas florestas inundáveis da Amazônia Central. Revista Brasileira de Biologia, vol. 58, no. 2, p. 317-335.

FRANKLIN E., SANTOS, EMR. and ALBUQUERQUE, MIC., 2006. Diversity and distribution of oribatid mites (Acari: Oribatida) in a lowland rain forest of Peru and in several environments of the Brazilians states of Amazonas, Rondônia, Roraima and Pará. Brazilian Journal of Biology, vol. 67, no. 4, p. $999-1020$.

GISIN, H., 1943. Ökologie und Lebensgemeinschaften der Collembolen im Schweizerischen Exkursionsgebiet Basels. Revue Suisse de Zoologie, vol. 50, no. 4, p. 183-189.

GRANDJEAN, F., 1953. Essai de classification des Oribates (Acariens). Bull. Soc. Zool. France, vol. 78, p. 421-446.

-. 1965. Complément à mon travail de 1953 sur la classification des Oribates. Acarologia, vol. 7, p. 713-734."

-, 1969. Considération sur le classement des Oribates. Leurs division en 6 roupes majeurs. Acarologia, vol. 11, p. 127-153.

HANSEN, RA. and COLEMAN, DC., 1998. Litter complexity and composition of oribatid mites (Acari:Oribatida) in litterbags. Applied Soil Ecology, vol. 9, p. 17-23.

HAYEK, T., 2000. Ácaros do solo (ACARI: ORIBATIDA): diversidade, abundância e biomassa na decomposição de serapilheira em parcelas de floresta primária, capoeiras e policultivo da Amazônia Central. MSc. Thesis. Manaus, INPA, 93p.

LAVELLE, P. and SPAIN, AV., 2001. Soil Ecology. Kluwer Academic Publishers, 654p.

LAWTON, JH., BIGNELL, DE., BOLTON, B., BLOEMERS, GF., EGGLETON, P., HAMMOND, PM., HODDA, M.,
HOLTS, RD., LARSEN, TB., MAWDSLEY, NA., STORK, NE., SRIVASTAVA, DS. and WATT, AD., 1998. Biodiversity inventories, indicator taxa and effects of habitat modification in tropical forests. Nature, vol. 391, no. 1, p. 72-75.

MARTIUS, C., HÖFER, H., GARCIA, MV., RÖMBKE, J. and HANAGARTH, W., 2004. Litter fall, litter stocks and decomposition rates in rainforest and agroforestry sites in central Amazonia. Nutrient Cycling in Agroecosystems, vol. 68, no. 2, p. $137-154$.

NOTI, M-I, ANDRÉ, HW., DUCARME, X. and LEBRUN, P., 2003. Diversity of soil oribatid mites (Acari:Oribatida) from High katanga (Democratic Republic of Congo): a multiscale and multifactor approach. Biodiversity and Conservation. vol. 12 , no. 4 , p. 767-785.

OLIVER, I., 1997. Future taxonomic partnerships: A reply to Goldstein. Conservation Biology, vol. 11, p. 575-576.

OLIVER I., PIK A., BRITTON D., DANGERFIELD, JM., BEATTIE AJ. and COLWELL, RK., 2000. Virtual biodiversity assessment systems: The application of bioinformatics technologies to the accelerated accumulation of biodiversity information. Bioscience, vol. 50, p. 441-50.

OLIVER, I. and BEATTIE, J., 2000. Virtual biodiversity assessment systems. Bioscience, vol. 50, no. 5, p. 441-450.

OLIVER, I. and BEATTIE, A., 1993. A possible method for the rapid assessment of biodiversity. Conservation Biology, vol. 7, p. $562-568$.

PIK, A., OLIVER, I. and BEATH, AJ., 1999. Taxonomic sufficiency in ecological studies of terrestrial invertebrates. Australian Journal of Ecology, vol. 24, p. 555-562.

RIBEIRO, EF., 1986. Oribatídeos (ACARI: ORIBATIDA) colonizadores de folhas em decomposição sobre o solo de três sítios florestais da Amazônia Central. MSc. Thesis. INPA, Manaus, $78 \mathrm{p}$.

RIBEIRO, EF. and SCHUBART, HOR., 1989. Oribatídeos (ACARI: ORIBATIDA) colonizadores de folhas em decomposição sobre o solo de três sítios florestais da Amazônia Central. Boletim do Museu Paraense Emílio Goeldi, vol. 5, no. 2, p. 243-276.

SUBIAS, LS., 2004, Listado Sistemático, Sinonímico y Biogeográfico de los Ácaros Oribátidos (Acariformes: Oribatida) del Mundo (Excepto fósiles). Graellsia, vol. 60, (número extraordinario), p. 3-305.

USHER, MB., 1988. Soil invertebrates: species populations, communities, modeling and conservation with special reference to the African Continent. Journal of African Zoology, vol. 102, p. 285-300.

WALLWORK, JA. 1967. Acari. In BURGES, A. and RAW, F. (ed.), Soil Biology. Academic Press, London, p. 487-532.

WOAS, S., 2002. Acari. In ADIS J. (ed.): Amazonian Arachnida and Myriapoda. Pensoft, Sofia-Moscow, p. 21-291.

WUNDERLE, I., 1985. Ein faunistich-ökologischer vergleich der Baum- und Bodenbewohnenden Oribatiden (Acari) im Tieflanderegenwald von Panguana, Peru. MSc. thesis. Univerdität Karlsruhe 103 p.

WUNDERLE, I., 1992. Arboricolous and edaphic Oribatei (Acari) in the lowland rain forest of Panguana, Peru. Amazoniana, vol. xii, no. 1, p. 119-142. 